\title{
Diversity and abundance of arbuscular mycorrhizal fungi associated with acacia trees from different land use systems in Ethiopia
}

\author{
Zerihun Belay $^{1 \star}$, Mauritz Vestberg ${ }^{2}$ and Fassil Assefa ${ }^{1}$ \\ ${ }^{1}$ Department of Microbial, Cellular and Molecular Biology, College of Natural Sciences, Addis Ababa University, Ethiopia. \\ ${ }^{2}$ Plant Production Research, Horticulture, MTT Agrifood Research Finland, Antinniementie 1, FI-41330 \\ Vihtavuori, Finland. \\ Accepted 8 October, 2013
}

\begin{abstract}
Root samples and rhizosphere soil of nine acacia species (Acacia abyssinica, Faidherbia albida, $A$. nilotica, A. senegal, A. seyal, A. sieberiana, A. saligna, A. tortilis and A. robusta) were collected from Bishoftu, Zeway and Addis Ababa sites with different land use types to assess their Arbuscular Mycorrhizal Fungal (AMF) diversity, spore density and root colonization. The percentage of root length colonized by AMF was estimated. Spores, spore clusters and sporocarps extracted from soil samples were counted and morphologically identified to species or specific morphotype. Roots of all acacia species were colonized from low to moderate or relatively high levels by AMF with the occurrence of arbuscules, vesicles and hyphae. Arbuscules were however not detected in roots of $A$. senegal. The highest AM fungal colonization was found in $A$. seyal (67.3\%) from open grazing field (OGF) at Zeway followed by $A$. nilotica (44\%), whereas the lowest AMF colonization of $12 \%$ was recorded in $A$. saligna at Bishoftu. Rhizosphere soils harbored AMF fungal spores ranging from 3.7 spores $\mathrm{g}^{-1}$ soil in A. nilotica to 15.0 spores $\mathrm{g}^{-1}$ in $A$. seyal from open grazing field (OGF) at Zeway. A total of 41 AMF species in 14 genera and 7 families of the Glomeromycota were identified. Nine species belonged to Acaulospora, 6 to Funneliformis, 4 each to Gigaspora, Glomus, and Rhizophagus, 3 each to Claroideoglomus, and Scutellospora, 2 each to Racocetra and Diversispora, and 1 each to Entrophospora, Sclerocystis, Paraglomus and Pacispora. Moreover, 2 unidentified morphotypes each of Glomus, and Acaulospora and 1 of Archaeospora were isolated. Based on relative abundance and isolation frequency of spores, $C$. claroideum, C. etunicatum, C. Iuteum, F. geosporus and G. aggregatum were the dominant species in the study. The study showed that the acacia species were characterized by relatively high AMF colonization and very high AMF diversity. AMF spore density and AM root colonization in acacia roots were influenced by soil factors such as available $P$ and soil texture.
\end{abstract}

Key words: Acaulospora, AM colonization, Arbuscules, Funneliformis, Glomeromycota, Rhizosphere soils.

\section{INTRODUCTION}

The acacia trees are important legumes in the tropics represented by more than 1200 species (Anon, 1983). They are multi-purpose and fast growing woody plants used as fuel wood, fodder, for improving soil fertility and as shade for planting crops (Brewbaker, 1986). Acacia species with few exceptions nodulate and fix nitrogen with root nodule bacteria to the tune of 20 to $300 \mathrm{~kg}$ ha${ }^{1} \mathrm{yr}^{1}{ }^{1}$ (Dommergues, 1987), and symbiotically associated with Arbuscular Mycorrhizal Fungi (AMF) which is a widespread phenomenon occurring in more than $80 \%$ of 
terrestrial plants (Smith and Read, 2008). AMF enhance nutrient, particularly phosphorus $(P)$, and water uptake by acacia species and improves their nitrogen fixation which enables them to establish them in marginalized lands in the tropics (Requena et al., 2001). These associations contribute to their tolerance to drought, and induce resistance against soil pathogens (Smith and Read, 2008). These associations, in general, enable many of the acacia species perform well in degraded soils with high acidity, high salinity, high aluminum saturation and low soil fertility (Craig et al., 1991). Consequently, acacia trees/shrubs are integrated in the traditional agroforestry systems and for the rehabilitation of fast disappearing and marginalized agro-ecosystems in the tropics and subtropics (Ngulube et al., 1993).

In Ethiopia, the genus Acacia is the third dominant group of woody leguminous plants, represented by more than 49 indigenous species, and widely distributed in altitudes ranging from 0 to $3400 \mathrm{~m}$ a.s.l (Hunde and Thulin, 1989). The legume is the most important component of the acacia woodland, which is the major vegetation from the arid and semi- arid parts of Ethiopia being utilized in many different ways for the rural economy, and to rehabilitate and stabilize degraded ecosystem especially in the Rift Valley of Ethiopia (Eshete and Stahl, 1999). Although, several studies have been carried out in relation to diversity and density of AMF on coffee and shade trees in montaine forests (Wubet et al., 2003; Muleta et al., 2007), and in the dry deciduous woodlands of Northern Ethiopia (Birhane et al., 2010), studies on the AMF-acacia relationship was limited to the co-inoculation of AMF and rhizobia. The AMF species found in earlier studies of acacia trees belong mainly to the genera Glomus and Gigaspora (Michelson, 1993; Yohannes and Assefa, 2009). However, currently there is an increase in the land use change for crop production in the country.

The Rift Valley area is one of the regions that suffer most from rapid deforestation that has led to the decrease in the biodiversity of the woodlands for intensive agriculture and settlement for the ever increasing small-hold farming community (Garedew et al., 2009). It is also established that agricultural development can change the whole spectrum of AMF associations that are specifically associated with fitness of specific plants, plant community structure and ecological variability (Van der Heijden et al., 1998). Sanders et al. (1996) reported that plant species respond differently to different AMF species and, density and diversity of naturally occurring AMF were reduced, particularly in disturbed arid and semi arid habitats (Mason and Wilson, 1994). Oehl et al. (2003) also reported that increased land use intensity was correlated with a decrease in AMF species richness and with a preferential selection of species in agroecosystems of Central Europe. Another study in Mexican also showed that land use change from temperate forest to avocado plantation had minimal effect on AMF commu- nities, but conversion of forests to maize fields reduced AMF diversity (González-Cortés et al., 2012). Several studies concerning AMF and land use systems have been conducted in tropical ecosystems.

In a study with Acacia senegal in the sahelian regions of Senegal, Ndoye et al. (2012) found that the positive effects of this plant species on AMF spore density and diversity as well as on soil microbial functions can be influenced by land-use systems (plantations versus natural populations of $A$. senegal). In tropical dry ecosystems of Mexico, Gavito et al. (2008) found higher AMF morphospecies richness in primary forests than in secondary forests and pastures. In a Brasilian study (da Silva Sousa et al., 2013), the presence of trees (gliricída and maniçoba) increased sporulation, mycorrhizal colonization and the production of infective propagules of AMF in three land use systems. This, therefore, necessitates exhaustive research on the relationship between land use changes and mycorrhizal diversity and density for, any success in rehabilitation for establishment of seedlings depends upon the mycorrhizas in the terrestrial ecosystems (Wubet et al., 2003).

The objective of this investigation was to study the arbuscular mycorrhizal fungal colonization, spore density and diversity of nine acacia species that grow in different land use systems in woodland and savanna woodland vegetation from parts of arid and semi- arid areas of the Rift Valley of Ethiopia.

\section{MATERIALS AND METHODS}

\section{Sampling sites}

Acacia trees were sampled from three sites, that is, Addis Ababa (2400 m a.s.l.) and Bishoftu and Zeway in the Rift Valley system (1600 to $1960 \mathrm{~m}$ a.s.I.). The Addis Ababa site is a high woodland system, while the Rift Valley sites are naturally characterized by woody grassland dominated by different acacia species (Hunde and Thulin, 1989). The sampling areas were represented by six different land use types and vegetation cover. The Addis Ababa site was a (1) protected park (PP). Land use types occurring at Zeway were (2) sorghum cropping in agro-forestry system (SCAFS), (3) protected forest relics managed by Hawassa University (PFR-HU), (4) protected forest relics with natural vegetation (PFRNV) and (5) open grazing field (OGF). The land use type at Bishoftu was a (6) community preserved forest relics for reforestation programmes (CPFR) (Figure 1 and Table 1). Nine acacia tree species (Acacia abyssinica, A. nilotica, A. robusta, A. saligna, A. senegal, A. seyal, A. sieberiana, $A$. tortilis and Faidherbia albida) were studied. Of these $A$. saligna is an Australian origin while all the other ones are native to Africa. Sampling was conducted during dry seasons from November 2010 to December 2011. The average annual temperature and precipitation of Addis Ababa, Bishoftu and Zeway were 17,20 and $22^{\circ} \mathrm{C}$, and 44,35 and $74 \mathrm{~mm}$, respectively.

\section{Soil and root sampling}

Three separate sample locations were established at each land use type in each site. Within each of these locations (approximately 100 


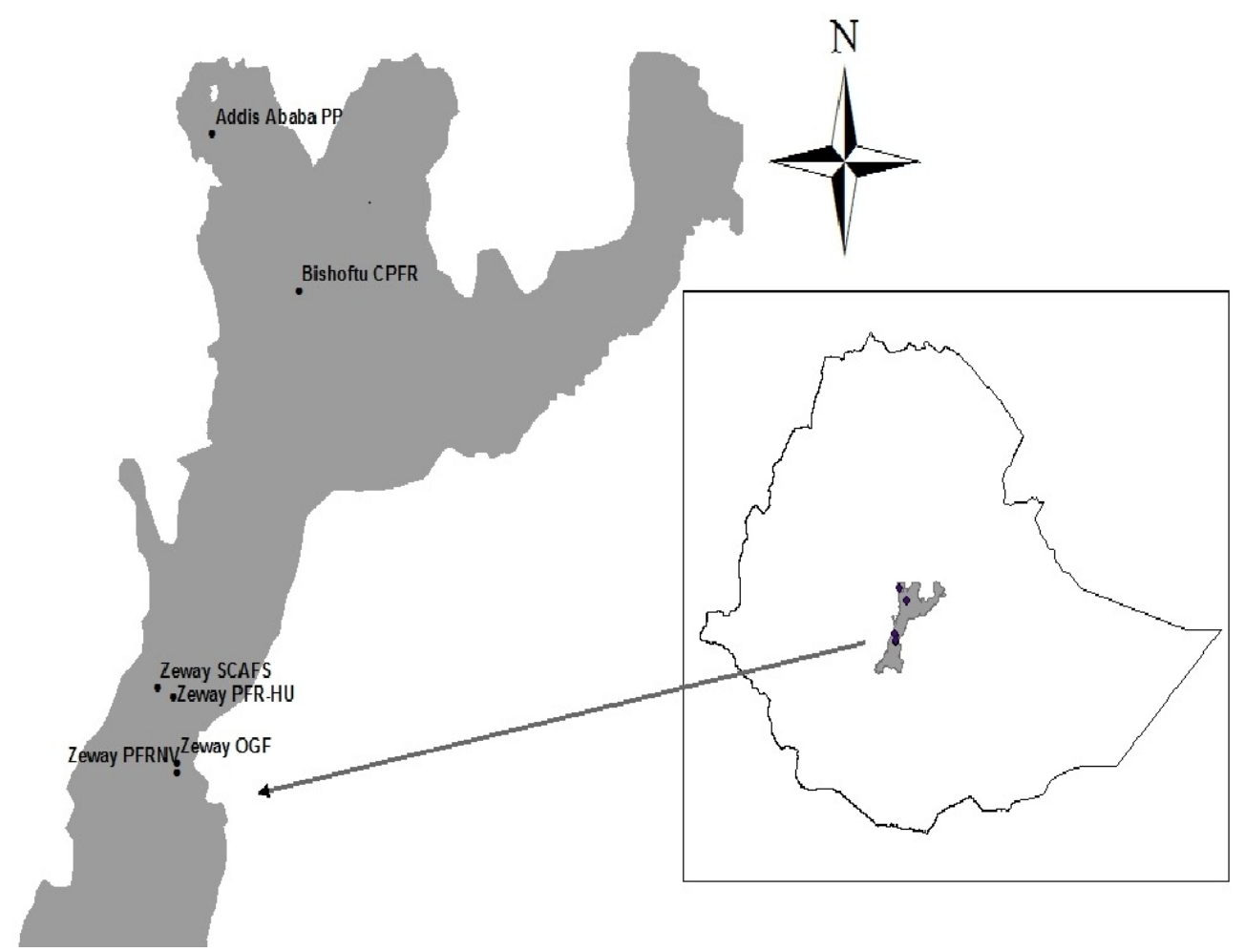

Figure 1. Map of the study site and sampling location.

Table 1. List of acacia species studied from different land use types of the sampling sites.

\begin{tabular}{|c|c|c|c|c|c|}
\hline $\begin{array}{l}\text { Name of the acacia } \\
\text { species }\end{array}$ & $\begin{array}{c}\text { Plant density/100 } \\
\mathrm{m}^{2}\end{array}$ & Agro-ecology & $\begin{array}{l}\text { Altitude } \\
(\mathrm{m})\end{array}$ & Sampling sites & Land use type \\
\hline A. abyssinica & 2 & Woodland and forest margins & 2400 & Addis Ababa & PP \\
\hline F. albida & 10 & Wooded grassland & 1661 & Zeway & SCAFS \\
\hline A. nilotica & 15 & Wooded grass land & 1660 & Zeway & PFR-HU \\
\hline A. senegal & 15 & \multirow{3}{*}{ Wooded grass land } & \multirow{3}{*}{1650} & \multirow{3}{*}{ Zeway } & \multirow{3}{*}{ PFRNV } \\
\hline A. tortilis & 15 & & & & \\
\hline A. seyal & 10 & & & & \\
\hline A. tortilis & 10 & \multirow{2}{*}{ Wooded grass land } & \multirow{2}{*}{1651} & \multirow{2}{*}{ Zeway } & \multirow{2}{*}{ OGF } \\
\hline A.seyal & 10 & & & & \\
\hline A. sieberiana & 12 & \multirow{4}{*}{ Wooded grass land } & \multirow{4}{*}{1954} & \multirow{4}{*}{ Bishoftu } & \multirow{4}{*}{ CPFR } \\
\hline A. saligna & 15 & & & & \\
\hline A. seyal & 15 & & & & \\
\hline A. robusta & 10 & & & & \\
\hline
\end{tabular}

m: Meter; PP: protected park; SCAFS: sorghum cropping in agro-forestry system; PFR-HU: protected forest relics managed by Hawassa University; PFRNV: protected forest relics with natural vegetation; OGF: open grazing field; CPFR: community preserved forest relics for reforestation programmes.

$\mathrm{m}^{2}$ ), three replicates of each acacia tree species were randomly selected and $500 \mathrm{~g}$ of rhizosphere soil and fine roots of the selected trees were taken into a depth of $30 \mathrm{~cm}$ and that were pooled into a composite sample per location (Table 1). The samples were collected in alcohol sterilized plastic containers and stored at room temperature until further analysis. Root samples were washed with 
tap water and stored in $50 \%$ of alcohol at $4^{\circ} \mathrm{C}$ before determination of root colonization by AM fungi. Soil chemical and physical parameters such as $\mathrm{pH}$, organic carbon (OC), total nitrogen (TN), available phosphorus $(\mathrm{P})$ and soil texture were determined using standard methods at the Addis Ababa city administration environmental protection authority (Table 2). Voucher specimens of the acacia trees were brought and deposited at the National Herbarium, Addis Ababa University for identification.

\section{Assessment of AMF root colonization}

The stored root samples were washed carefully with tap water and cut into segments about $1 \mathrm{~cm}$ long. About $0.5 \mathrm{~g}$ of root segments were cleared in $10 \%(\mathrm{w} / \mathrm{v}) \mathrm{KOH}$ at $90^{\circ} \mathrm{C}$ in a water bath for 2 to $3 \mathrm{~h}$ depending on the structure of the root and its pigmentation (Brundrett et al., 1996). Dark roots were further bleached with alkaline hydrogen peroxide $\left(\begin{array}{lll}10 \% & \mathrm{H}_{2} \mathrm{O}_{2}\end{array}\right)$ for $3 \mathrm{~min}$ at room temperature. Thereafter, the roots were treated with $10 \% \mathrm{HCl}(\mathrm{v} / \mathrm{v})$ for 15 to $20 \mathrm{~min}$ at room temperature and finally stained in $0.05 \%$ $w / v$ trypan blue in lactoglycerol (1:1:1 lactic acid, glycerol and water) at $90^{\circ} \mathrm{C}$ for $30 \mathrm{~min}$ in a water bath (Brundrett et al., 1996). Fungal colonization was quantified using the magnified intersection method of McGonigle et al. (1990) under a compound-light microscope (OLYMPUS-BX51) at a magnification x200. Accordingly, 150 intersections were observed for each sample. The presence of arbuscular mycorrhizal hyphae, vesicles and arbuscules were recorded.

\section{Spore extraction and identification}

Soil samples were air-dried before extraction, counting and identification of AM fungal spores. The AMF spores present were morphologically identified at the Department of Microbial, Cellular and Molecular Biology, Addis Ababa University, Ethiopia and Agrifood Research Finland (MTT), Laukaa, Finland. AMF spores occurring in the soil samples were extracted by the wet sieving and decanting method (Gerdemann and Nicolson, 1963), followed by centrifugation in water and in $50 \%$ sucrose solution (Walker et al., 1982). Sieves of size of 500,250 and $50 \mu \mathrm{m}$ were used for the wet sieving procedure. Spores, spore clusters and sporocarps obtained from 250 and $50 \mu \mathrm{m}$ sieves were counted and observed by using a dissecting microscope. Thereafter, spores were mounted on slides in polyvinyl-lactic acid-glycerol (PVLG) (Omar et al., 1979) or in PVLG mixed with Melzer's reagent $(1: 1 \mathrm{v} / \mathrm{v})$. Spores were examined under a compound microscope and identified to the species level or attributed to a specific morphotype.

Identification and classification were based on a current species descriptions and identification manual (Schenck and Perez, 1990), online references of species description INVAM http://invam.caf.wvu.edu, University of Agriculture in Szczecin, Poland http://www.zor.zut.edu.pl/Glomermycota/, Schüßler and Walker (2010) and the Schüßler AMF phylogeny website http://www.Irz.de/ schuessler/amphylo/

\section{Statistical analysis}

Spore density (SD) was expressed as the number of AMF spores per gram of soil. Species richness (SR) was measured as a number of AMF species per sample. Isolation frequency (IF) is (the number of samples in which a given species was isolated / the total number of samples) $\times 100 \%$. Relative abundance of spores $(R A)$ is (the number of spores in a given species / total number of spores) $\times$ $100 \%$. The dominant AMF species were determined according to relative abundance $(\mathrm{RA}>5 \%$ ) and isolation frequency (IF $>50 \%)(\mathrm{Li}$ et al., 2007). Analysis of variance (ANOVA) and correlation analysis were carried out with the SPSS software package (version 18.0). Transformed data were subjected to one-way ANOVA to test the differences in $\mathrm{AM}$ colonization and spore density among plant species. Multiple mean comparisons were performed using Tukey's HSD post hoc test at the 0.05 level of probability with one-way ANOVA. The relationship between AM colonization and spore density as well as spore density, and species richness and soil parameters were determined by Pearson's correlation analysis.

\section{RESULTS}

\section{AMF root colonization}

Acacia roots showed mycorrhization with typical structures (arbuscules, hyphae and vesicles) except that arbuscules were not detected in $A$. senegal (data not shown). AMF root colonization varied from 12 to $67.3 \%$ (Table 3$)$. The highest colonization $(67.3 \%)$ was found in $A$. seyal from OGF followed by $44 \%$ colonization in $A$. nilotica from PFR-HU, whereas, $A$. saligna from CPFR showed the lowest AM fungi colonization (12\%). Arbuscule and vesicle colonization were the highest in the roots of $A$. seyal from OGF, 11.8 and $17.3 \%$, respectively. In contrast, low percentages of arbuscules $(0 \%)$ and vesicles (1.6\%) were recorded from roots of $A$. senegal (PFRNV) and from $A$. abyssinica (PP), respectively. The percentage of AMF root colonization of the same species from different land use types did not show significant difference except, that the percentage of vesicles recorded from $A$. seyal (17.3\%) at OGF, was significantly higher than that of the same plant species (8\%) from PFRNV (Table 3). The data also shows slight but not significant negative correlation between the root colonization levels and the available $\mathrm{P}$ concentration in soil $(r=-0.40)$. However, arbuscular colonization was strongly correlated with vesicular and hyphal colonization $\left(R^{2}=0.76\right.$ and $r^{2}=0.67$, respectively; $\left.p<0.05\right)$.

\section{AMF spore density and species diversity}

Rhizosphere soils from all acacia species in different land use systems harbored high numbers of AMF spores ranging from 3.7 to 15.0 spores $\mathrm{g}^{-1}$ soil with an average of 9.9 spores $\mathrm{g}^{-1}$ soil (Figure 2). The highest average spore density of 15.0 spores $\mathrm{g}^{-1}$ soil was observed under $A$. seyal (OGF), and the lowest of 3.7 spores $\mathrm{g}^{-1}$ of soil under $A$. nilotica. Significant difference $(p<0.05)$ in spore density was observed between $A$. seyal $\left(15.0 \mathrm{~g}^{-1}\right), A$. abyssinica $\left(7.5 \mathrm{~g} \mathrm{~g}^{-1}\right)$, A. robusta $\left(7.3 \mathrm{~g}^{-1}\right)$ and A. nilotica $\left(3.7 \mathrm{~g}^{-1}\right)$. Similarly, spore numbers obtained under $A$. senegal (11.9 spores $\mathrm{g}^{-1}$ of soil), A. tortilis $\left(12.6 \mathrm{~g} \mathrm{~g}^{-1}\right)$ from PFRNV, A. sieberiana $\left(11.5 \mathrm{~g}^{-1}\right)$ and $A$. seyal $\left(12.7 \mathrm{~g}^{-1}\right)$ from CPFR were significantly different from spore numbers obtained under $A$. nilotica (3.1 spores $\mathrm{g}^{-1}$ of soil). Though, not statistically significant there was an indication of slightly higher spore density in the rhizosphere soil of $A$. seyal from OGF (15.0 spores $\mathrm{g}^{-1}$ of 
Table 2. Physical and chemical parameters of soil samples from the acacia trees.

\begin{tabular}{|c|c|c|c|c|c|c|c|c|c|c|}
\hline Name of the acacia species & $\mathrm{pH}$ & $\begin{array}{l}\text { T.N } \\
(\%)\end{array}$ & $\begin{array}{l}\text { Avail. P } \\
\text { (ppm) }\end{array}$ & $\begin{array}{l}\text { O.C } \\
(\%)\end{array}$ & $\mathrm{C} / \mathrm{N}$ & $\begin{array}{l}\text { Clay } \\
(\%)\end{array}$ & $\begin{array}{l}\text { Silt } \\
(\%)\end{array}$ & $\begin{array}{l}\text { Sand } \\
(\%)\end{array}$ & Soil class & Land use type \\
\hline A. abyssinica & 6.8 & 0.19 & 24.54 & 2.95 & 16 & 46 & 20 & 34 & Clay & $\mathrm{PP}$ \\
\hline F. albida & 7.2 & 0.15 & 5.82 & 2.02 & 14 & 38 & 26 & 36 & Clay loam & SCAFS \\
\hline A. nilotica & 6.4 & 0.37 & 20.68 & 4.77 & 13 & 48 & 22 & 30 & Clay & PFR-HU \\
\hline A. senegal & 6.6 & 0.34 & 4.72 & 3.72 & 11 & 16 & 30 & 54 & Sandy loam & \multirow{3}{*}{ PFRNV } \\
\hline A. tortilis & 6.4 & 0.32 & 4.44 & 3.65 & 11 & 18 & 38 & 44 & Loam & \\
\hline A. seyal & 6.7 & 0.32 & 5.88 & 3.93 & 12 & 14 & 34 & 52 & Loam & \\
\hline A. tortilis & 6.5 & 0.33 & 5.42 & 4.02 & 12 & 18 & 34 & 48 & Loam & \multirow[b]{2}{*}{ OGF } \\
\hline A. seyal & 6.6 & 0.33 & 5.32 & 4.02 & 12 & 19 & 33 & 48 & loam & \\
\hline A. sieberiana & 6.4 & 0.08 & 13.06 & 1.58 & 20 & 22 & 24 & 54 & Sandy clay loam & \multirow{4}{*}{ CPFR } \\
\hline A. saligna & 6.5 & 0.12 & 12.88 & 1.75 & 15 & 44 & 24 & 32 & Clay & \\
\hline A. seyal & 6.5 & 0.15 & 4.47 & 1.92 & 13 & 24 & 30 & 46 & Loam & \\
\hline A. robusta & 6.5 & 0.21 & 13.86 & 3.15 & 15 & 26 & 24 & 50 & Sandy clay loam & \\
\hline
\end{tabular}

T.N: Total nitrogen; Avail. P: available phosphorus; O.C: organic carbon; C/N: carbon nitrogen ratio; PP: protected park; SCAFS: sorghum cropping in agro forestry system; PFR-HU: protected forest relics managed by Hawassa University; PFRNV: protected forest relics with natural vegetation; OGF: open grazing field; CPFR: community preserved forest relies for reforestation programmes.

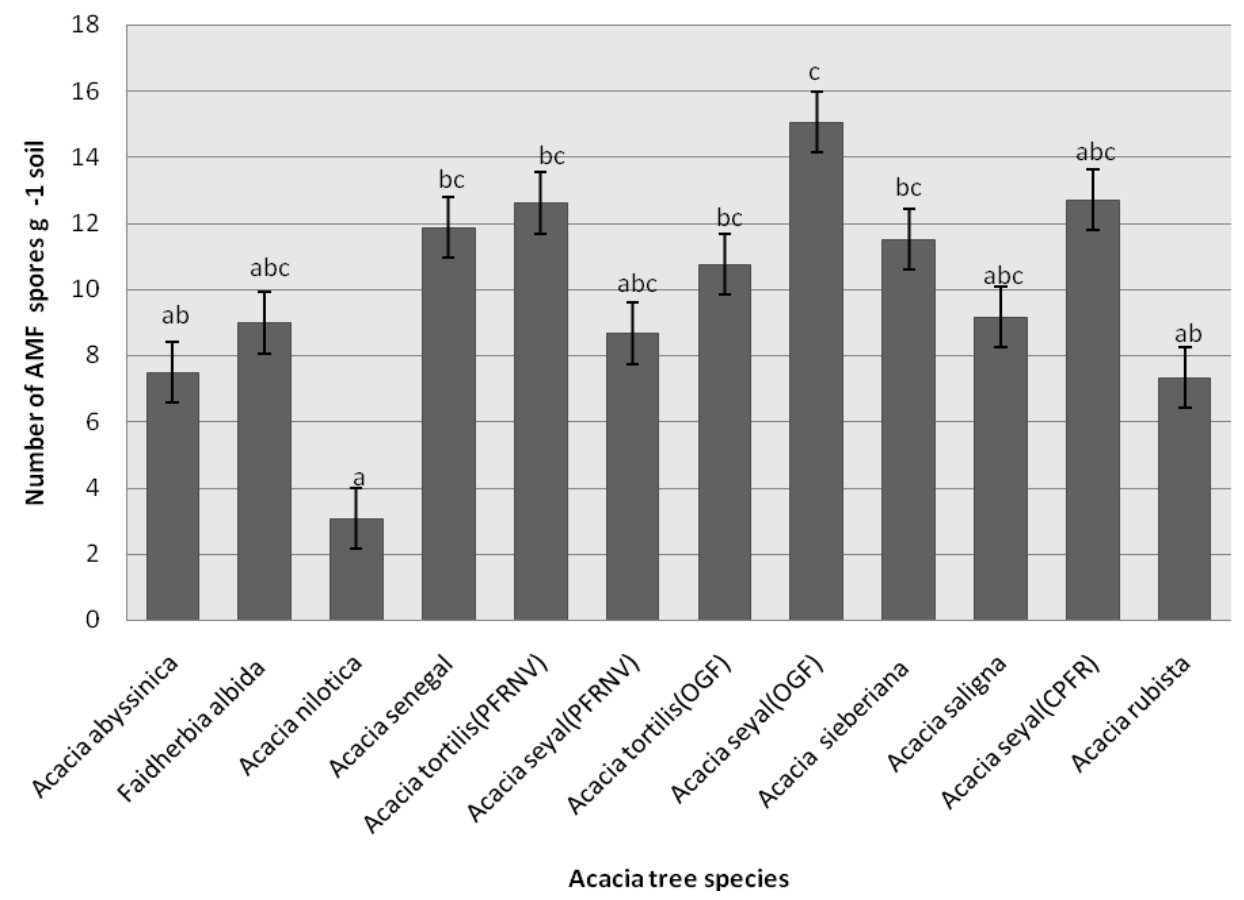

Figure 2. AMF spore abundance in rhizosphere soil of acacia species. Data are reported as (mean \pm SE) for three replicate per samples. Significant differences between the samples are indicated by different letters above the bars and were determined by using Tukey HSD at the 0.05 level after one -way ANOVA; PFRNV: protected forest relics with natural vegetation; OGF: open grazing field; CPFR: community preserved forest relies for reforestation programmes.

soil) than in the rhizosphere soil of the same acacia species from forest relics in Bishoftu and Zeway (12.7 spores $\mathrm{g}^{-1}$ and 8.7 spores $\mathrm{g}^{-1}$ of soil, respectively). Correlation analysis showed a significant negative corre- 
Table 3. Percentage of AMF roots colonization of roots in rhizosphere soil of acacia trees.

\begin{tabular}{lcccl}
\hline \multirow{2}{*}{ Name of the acacia species } & \multicolumn{3}{c}{ AM colonization } & Land use type \\
\cline { 2 - 4 } & AC (\%) & VC (\%) & HC (\%) & \\
\hline A. abyssinica & $1.4 \pm 0.8^{\mathrm{a}}$ & $1.6 \pm 0.9^{\mathrm{a}}$ & $15.3 \pm 3.8^{\mathrm{a}}$ & PP \\
F. albida & $1.7 \pm 0.3^{\mathrm{a}}$ & $1.7 \pm 0.3^{\mathrm{a}}$ & $24.5 \pm 0.8^{\mathrm{a}}$ & SCAFS \\
A. nilotica & $2.8 \pm 1^{\mathrm{a}}$ & $8.9 \pm 0.2^{\mathrm{ab}}$ & $44 \pm 1.1^{\mathrm{ab}}$ & PFR-HU \\
& & & & \\
A. senegal & 0 & $3.1 \pm 1.7^{\mathrm{a}}$ & $20.2 \pm 7.3^{\mathrm{a}}$ & \\
A. tortilis & $6.6 \pm 1.9^{\mathrm{ab}}$ & $6.9 \pm 1.5^{\mathrm{a}}$ & $37.6 \pm 5.4^{\mathrm{ab}}$ & PFRNV \\
A. seyal & $2.8 \pm 1^{\mathrm{ab}}$ & $8 \pm 1.1^{\mathrm{a}}$ & $38 \pm 1.7^{\mathrm{ab}}$ & \\
& & & & \\
A. tortilis & $2.3 \pm 0.2^{\mathrm{a}}$ & $2.3 \pm 1.3^{\mathrm{a}}$ & $37.5 \pm 2^{\mathrm{ab}}$ & \\
A. seyal & $11.8 \pm 3.9^{\mathrm{b}}$ & $17.3 \pm 1.3^{\mathrm{b}}$ & $67.3 \pm 4.4^{\mathrm{b}}$ & OGF \\
& & & & \\
A. sieberiana & $4.5 \pm 2.5^{\mathrm{ab}}$ & $4.5 \pm 2.5^{\mathrm{a}}$ & $32.3 \pm 18^{\mathrm{ab}}$ & \\
A. saligna & $2.5 \pm 1.4^{\mathrm{a}}$ & $5 \pm 2.8^{\mathrm{a}}$ & $12 \pm 6.9^{\mathrm{a}}$ & \\
A. seyal & $3.3 \pm 1.9^{\mathrm{ab}}$ & $10.3 \pm 1.2^{\mathrm{ab}}$ & $28.5 \pm 11^{\mathrm{ab}}$ & CPFR \\
A. robusta & $2.5 \pm 1.4^{\mathrm{a}}$ & $5.0 \pm 2.8^{\mathrm{a}}$ & $23.7 \pm 6.4^{\mathrm{a}}$ & \\
\hline
\end{tabular}

Significant differences between the samples are indicated by different letters in column and were determined by using Tukey HSD at the 0.05 level after one -way ANOVA. AC, VC and HC are percentage of root length with arbuscule, vesicle and hyphal colonization, respectively; PP: protected park; SCAFS: sorghum cropping in agro forestry system; PFR-HU: protected forest relics managed by Hawassa University; PFRNV: protected forest relics with natural vegetation; OGF: open grazing field; CPFR: community preserved forest relies for reforestation programmes.

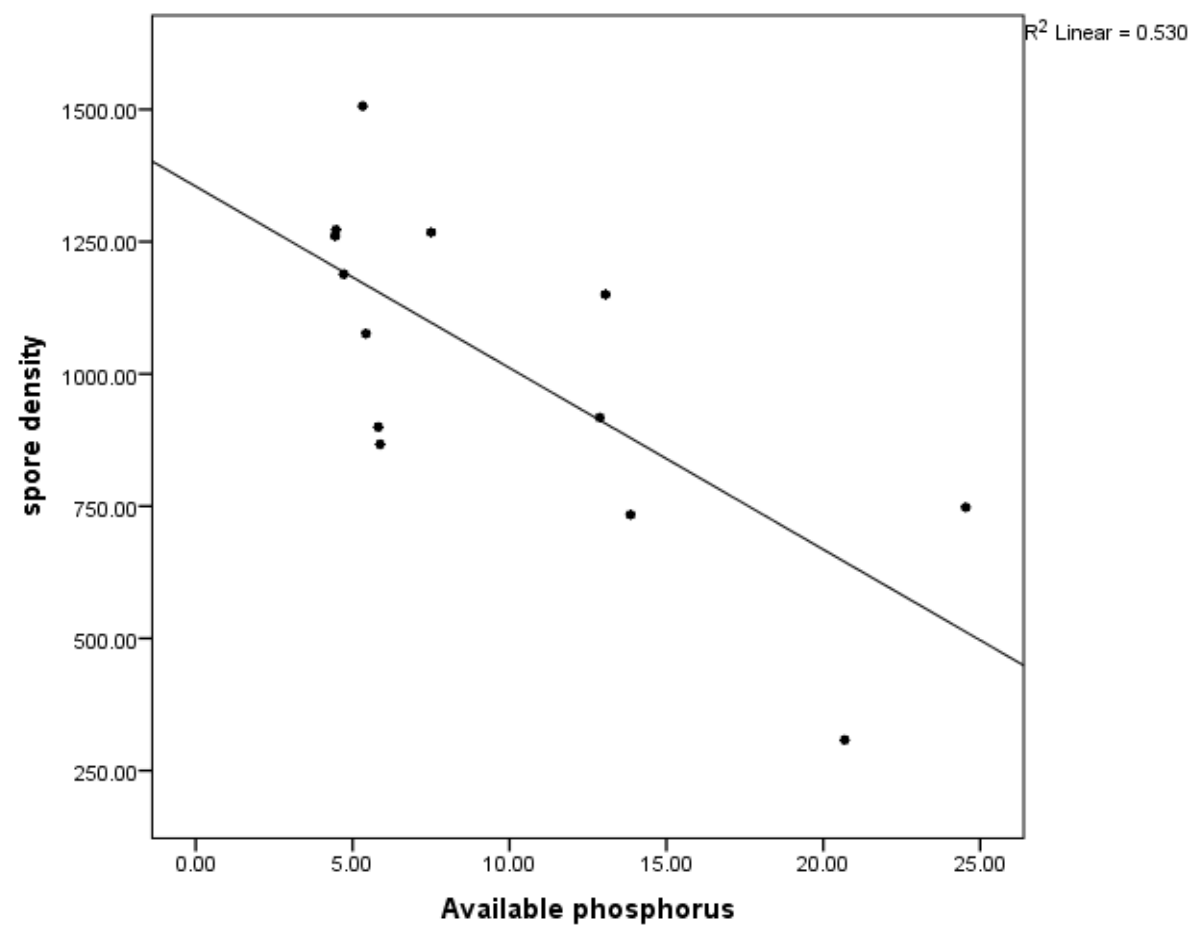

Figure 3. Correlation between available phosphorus and spore density.

lation between AMF spore density and available $P$ in soil $(r=0 .-728, p<0.01)$ (Figure 3). AMF spore density was positively correlated with the percentage of soil texture such as silt and sand $(r=0.649$ and $0.604, p<0.05$, respectively), but negatively correlated with the percentage of clay $(r=-0.710, p<0.01)$. 


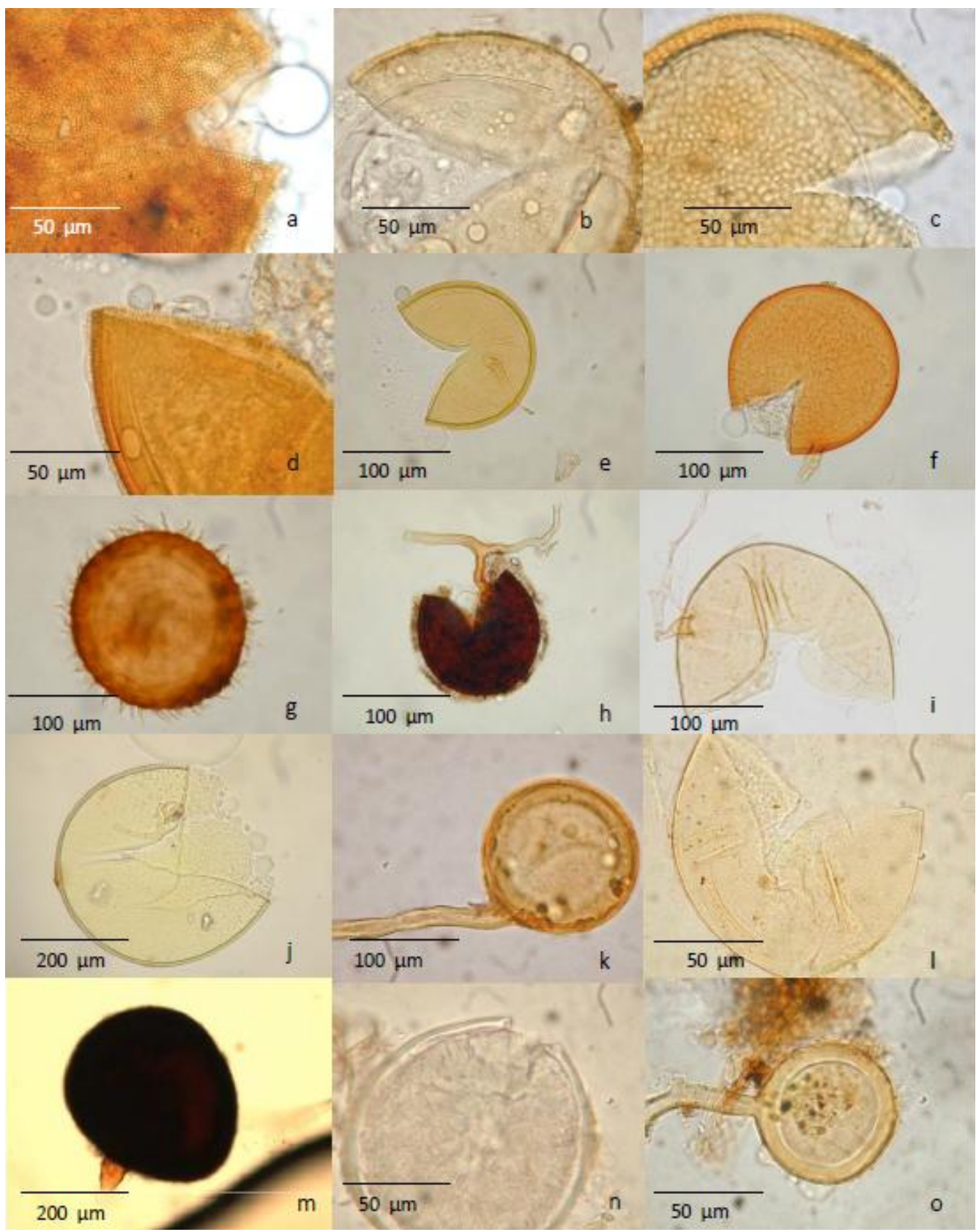

Figure 4. Some Glomeromycotan species identified from rhizosphere soil samples of acacia species in Ethiopia. All photos are from slides made in PVLG. a) Acaulospora dentidulata, b) A. kentiniensis, c) A. scrobiculata, d) A. spinosa, e) Claroideoglomus claroideum, f) Diversispora epigaea, g) Entrophospora nevadensis, h) Funneliformis geosporus, i) F. mosseae, j) Gigaspora gigantea, k) Glomus hoi, I) Pacispora scintillans, m) Racocetra gregaria, n) Rhizophagus diaphanus, o) $R$. fasciculatus.

A total of 41 AMF species belonging to 14 genera and seven families were identified from all rhizosphere soil samples of acacia species (Table 4 and Figure 4). Nine species belonged to Acaulospora, 6 to Funneliformis, 4 each to Gigaspora, Glomus, and Rhizophagus, 3 each to Claroideoglomus, and Scutellospora, 2 each to Racocetra and Diversispora, and 1 each to
Entrophosphora, Sclerocystis, Paraglomus and Pacispora (Table 4). Additionally, 2 unidentified morphotypes each of Glomus, and Acaulospora and 1 of Archaeospora were also observed. The highest species diversity of 19 species from 7 genera was detected in the rhizosphere soil of $A$. saligna followed by 18 species from $A$. abyssinica representing 6 genera. The lowest species 
Table 4. Identified arbuscular mycorrhizal fungi, their frequency of occurrence and relative abundances in rhizosphere soil of acacia species.

\begin{tabular}{|c|c|c|c|c|c|c|c|c|c|c|c|c|c|c|}
\hline AMF species & A. abyssinca & F. albida & A. nilotica & A. senegal & $\begin{array}{l}\text { A. tortilis } \\
\text { (PFRNV) }\end{array}$ & $\begin{array}{l}\text { A. seyal } \\
\text { (PFRNV) }\end{array}$ & $\begin{array}{l}\text { A. tortilis } \\
\text { (OGF) }\end{array}$ & $\begin{array}{l}\text { A. seyal } \\
\text { (OGF) }\end{array}$ & A. sieberiana & A. saligna & $\begin{array}{l}\text { A. seyal } \\
\text { (CPFR) }\end{array}$ & A. robusta & $\begin{array}{l}\text { IF } \\
(\%)\end{array}$ & $\begin{array}{l}\text { RA } \\
(\%) \\
\end{array}$ \\
\hline Acaulospora & & & & & & & & & & & & & 158 & 6.85 \\
\hline A. capsicula Błaszk. & & & & $x$ & & & & & & & & & 8.3 & 0.25 \\
\hline A. cavarnata Błaszk. & & & & & & & & & & $x$ & & & 8.3 & 0.25 \\
\hline A. denticulata Sieverd. \& S. Toro & & $x$ & & & & & & & & $x$ & $x$ & $x$ & 33.3 & 1.79 \\
\hline A. faveata Trappe \& Janos & $x$ & & & & & & & & & & & & 8.3 & 0.25 \\
\hline A. laevis Gerd. \& Trappe & & & & & & & & & & $x$ & & & 8.3 & 0.25 \\
\hline A. rehmii Sieverd. \& S. Toro & $x$ & & $x$ & & $x$ & & & & & & $x$ & & 33.3 & 1.53 \\
\hline A. sorbiculata Trappe & & & & & & & $x$ & & & & & $x$ & 16.6 & 1.02 \\
\hline A. spinosa Walker \& Trappe & $x$ & & & & & & & & $x$ & & & & 16.6 & 0.76 \\
\hline A. tuberculata Janos \& Trappe & & & & & $x$ & & & & & & & & 8.3 & 0.25 \\
\hline Acaulospora sp1 & & & & & & & & & & $x$ & & & 8.3 & 0.25 \\
\hline Acaulospora sp2 & & & & & & & & & $x$ & & & & 8.3 & 0.25 \\
\hline Archaeospora & & & & & & & & & & & & & 8.3 & 0.25 \\
\hline Archaeospora sp & & & & & & & & $x$ & & & & & 8.3 & 0.25 \\
\hline Claroideoglomus & & & & & & & & & & & & & 258 & 27.1 \\
\hline C. claroideum (Schenck \& Sm.) Walker \& Schuessler & $x$ & $x$ & $x$ & $x$ & & $x$ & $x$ & $x$ & $x$ & $x$ & $x$ & $x$ & 91.6 & 7.16 \\
\hline C. etunicatum (Becker \& Gerd.) Walker \& Schuessler & $x$ & $x$ & $x$ & $x$ & $x$ & & $x$ & $x$ & & $x$ & $x$ & & 75 & 5.37 \\
\hline C. luteum (Kenn, Stutz \& Morton) Walker \& Schuessler & $x$ & $x$ & $x$ & $x$ & $x$ & $x$ & $x$ & $x$ & $x$ & & $x$ & $x$ & 91.6 & 14.57 \\
\hline Diversispora & & & & & & & & & & & & & 24.9 & 1.27 \\
\hline D. celata Walker, Gamper \& Schuessler & $x$ & & & & & & & & & & & & 8.3 & 0.51 \\
\hline D. epigaea (Daniels \& Trappe) Walker \& Schuessler & & & & & $x$ & & & $x$ & & & & & 16.6 & 0.76 \\
\hline Entrophosphora & & & & & & & & & & & & & 8.3 & 0.25 \\
\hline $\begin{array}{l}\text { E. nevadensis Błaszk., Madej \& Tadych; Palenzuela, } \\
\text { Ferrol, Azcón-Aguilar \& Oehl }\end{array}$ & & & & & & & $\mathrm{x}$ & & & & & & 8.3 & 0.25 \\
\hline Funneliformis & & & & & & & & & & & & & 316 & 19.9 \\
\hline $\begin{array}{l}\text { F. badius (Oehl, Redecker \& Sieverd.) Walker \& } \\
\text { Schuessler }\end{array}$ & & & & & & $\mathrm{x}$ & & $\mathrm{x}$ & & & & & 16.6 & 1.53 \\
\hline F. caledonius (Nicolson \& Gerd.) Walker \& Schuessler & $x$ & & & $x$ & & & $x$ & & $x$ & $x$ & $x$ & & 50 & 1.53 \\
\hline F. constrictus (Trappe) Walker \& Schuessler & $x$ & $x$ & $x$ & $x$ & & & & & $x$ & $x$ & & $x$ & 58.3 & 4.34 \\
\hline F. coronatus (Giovann.) Walker \& Schuessler & & $x$ & & & & & & & & & & $x$ & 16.6 & 0.76 \\
\hline F. geosporus Nicolson \& Gerd.) Walker \& Schuessler & $x$ & & $x$ & $x$ & $x$ & $x$ & $x$ & $x$ & $x$ & $x$ & $x$ & $x$ & 91.6 & 6.9 \\
\hline $\begin{array}{l}\text { F. mossae (Oehl, Redecker \& Sieverd.) Walker \& } \\
\text { Schuessler }\end{array}$ & $x$ & $x$ & $x$ & $x$ & & $x$ & $x$ & $x$ & $x$ & $x$ & & & 83.3 & 4.85 \\
\hline Glomus & & & & & & & & & & & & & 275 & 24.5 \\
\hline
\end{tabular}


Table 4. Contd.

\begin{tabular}{|c|c|c|c|c|c|c|c|c|c|c|c|c|c|c|}
\hline G. aggregatum Schenck \& Sm. & $\mathrm{x}$ & $x$ & $x$ & $x$ & $\mathrm{x}$ & $x$ & $x$ & $x$ & & $x$ & $x$ & $\mathrm{x}$ & 91.6 & 13 \\
\hline G. hoi Berch \& Trappe & & & & & & & & & & $x$ & & & 8.3 & 0.25 \\
\hline G. microaggregatum (Koske, Gemma \& Olexia) & & & & & & & & & $x$ & $x$ & $x$ & & 25 & 1.02 \\
\hline G. microcarpum Tul. \& Tul. & $\mathrm{x}$ & & $x$ & $x$ & $x$ & $x$ & & $x$ & & & & & 50 & 4.6 \\
\hline Glomus sp1 (sporocarpic, thick wall \& smooth, $80-110 \mu \mathrm{m}$ ) & & & & & & & $x$ & & $x$ & $x$ & $x$ & $\mathrm{x}$ & 41.6 & 2.81 \\
\hline Glomus sp2 (red brown geosporum like) & $x$ & $\mathrm{x}$ & & $x$ & $\mathrm{x}$ & $\mathrm{x}$ & & $\mathrm{x}$ & $x$ & & & & 58.3 & 2.81 \\
\hline Rhizophagus & & & & & & & & & & & & & 66.5 & 2.54 \\
\hline R. clarus (Nicolson \& Schenck) Walker \& Schuessler & & & & & & & & & $x$ & & & & 8.3 & 0.25 \\
\hline R. diaphanus (Morton \& Walker) Walker \& Schuessler & & & $x$ & & & & & & & $\mathrm{x}$ & & & 16.6 & 0.76 \\
\hline R. fasciculatus (Thaxt.) Walker \& Schuessler & & & & & $\mathrm{x}$ & & & & & & $x$ & $\mathrm{x}$ & 25 & 1.02 \\
\hline R. intraradices (Schenck \& Sm.) Walker \& Schuessler & $x$ & & & & & & & $x$ & & & & & 16.6 & 0.51 \\
\hline Sclerocystis & & & & & & & & & & & & & 25 & 0.76 \\
\hline S. sinuosa Gerd. \& Bakshi & $x$ & & & & & & & $x$ & $x$ & & & & 25 & 0.76 \\
\hline Gigaspora & & & & & & & & & & & & & 58.2 & 2.28 \\
\hline G. albida Schenck \& Sm & & & & $x$ & & & $x$ & $x$ & & & & & 25 & 1.02 \\
\hline G. decipiens Hall \& Abbott & & & & & & & $x$ & & & & & & 8.3 & 0.25 \\
\hline G. gigantea (Nicolson \& Gerd.) Gerd. \& Trappe & & & & & & $x$ & & & & $x$ & & & 16.6 & 0.76 \\
\hline G. margarita Becker \& Hall & & $\mathrm{x}$ & & & & & & & & & & & 8.3 & 0.25 \\
\hline Racocetra & & & & & & & & & & & & & 41.6 & 2.55 \\
\hline R. fulgida (Koske \& Walker) Oehl, Souza \& Sieverd. & & $\mathrm{x}$ & & & & & & & & & & & 8.3 & 0.25 \\
\hline R. gregaria (Schenck \& Nicolson) Oehl, Souza \& Sieverd. & & $x$ & & $x$ & & & $x$ & $x$ & & & & & 33.3 & 2.3 \\
\hline Scutellospora & & & & & & & & & & & & & 108 & 6.59 \\
\hline S. calospora Nicolson \& Gerd.) Walker \& Sanders & & & & $\mathrm{x}$ & & & $\mathrm{x}$ & & & $\mathrm{x}$ & & & 25 & 1.79 \\
\hline S. cerradensis Spain \& Miranda & & & $x$ & $x$ & $x$ & & & $x$ & $x$ & & & & 41.6 & 2.3 \\
\hline S. pellucida (Nicolson \& Schenck) Walker \& Sanders & & $x$ & & $x$ & & $x$ & $x$ & & $x$ & & & & 41.6 & 2.5 \\
\hline Pacispora & & & & & & & & & & & & & 41.6 & 3.06 \\
\hline P. scintillans (Rose \& Trappe) Walker, Vestberg \& Schuessler & $x$ & & $x$ & & & & & $x$ & & $x$ & $x$ & & 41.6 & 3.06 \\
\hline Paraglomus & & & & & & & & & & & & & 41.6 & 1.79 \\
\hline P. occultum (Walker) Morton \& Redecker & $\mathrm{x}$ & $x$ & & & & $\mathrm{x}$ & $\mathrm{x}$ & & & $\mathrm{x}$ & & & 41.6 & 1.79 \\
\hline
\end{tabular}

PFRNV: Protected forest relies with natural vegetation; OGF: open grazing field; CPFR: community preserved forest relies.

diversity of 10 was detected from A. robusta, in 5 genera, and 11 species each from $A$. tortilis and $A$. seyal, with 6 and 5 genera, respectively (Table 5). Among land use types, the highest numbers of 31 AMF species in 9 genera were detected in
CPFR at Bishoftu and the lowest numbers of 6 species in 6 genera were in PFR-HU at Zeway (Table 5). Based on relative abundance and isolation frequency of spores, the 5 dominant species identified were $C$. claroideum, $C$. etunicatum, $C$. luteum, F. geosporus and G. aggregatum (Table 4). Generally, 32.6, 19.5 and $19.5 \%$ of AMF species were identified from the families of Glomeraceae, Acaulosporaceae and Gigasporaceae, respectively. However, most AMF species from the 
Table 5. Summary of total AMF genera and species identified in the plant species and land use types.

\begin{tabular}{|c|c|c|c|c|c|}
\hline \multirow{2}{*}{ Plant species } & \multicolumn{2}{|c|}{ Total AMF identified from the plants } & \multirow{2}{*}{ Land use type } & \multicolumn{2}{|c|}{ Total AMF identified in the land use type } \\
\hline & Genera & Species & & Genera & Species \\
\hline A. abyssinica & 8 & 18 & PP & 8 & 8 \\
\hline F. albida & 8 & 14 & SCAFS & 8 & 8 \\
\hline A. nilotica & 6 & 12 & PFR-HU & 6 & 6 \\
\hline A. senegal & 7 & 16 & & & \\
\hline A. tortilis & 6 & 11 & PFRNV & 9 & 22 \\
\hline A. seyal & 5 & 11 & & & \\
\hline A. tortilis & 9 & 16 & & & \\
\hline A. seyal & 9 & 17 & OGF & 11 & 25 \\
\hline A. sieberiana & 7 & 15 & & & \\
\hline A.saligna & 7 & 19 & CPFR & 9 & 31 \\
\hline A.seyal & 6 & 12 & UPFR & 9 & 31 \\
\hline A. robusta & 5 & 10 & & & \\
\hline
\end{tabular}

PP: Protected park; SCAFS: sorghum cropping in agro-forestry system; PFR-HU: protected forest relics managed by Hawassa University; PFRNV: protected forest relics with natural vegetation; OGF: open grazing field; CPFR: community preserved forest relies for reforestation programmes.

Acaulosporacae had low relative abundance and frequency of isolation compared to the other families.

\section{DISCUSSION}

In this study, we report AMF spore density, diversity and root colonization of selected species of acacia growing in different land use types in Ethiopia (Table 1). AMF were present in all roots and rhizosphere soil samples of acacia trees with low $(12 \%)$ to moderate $(67.3 \%)$ levels of colonization. This pattern is similar to that observed in other tropical systems such as (0 to $75 \%$ colonization) in acacia and other woody legume species in dry deciduous forest areas of Northern Ethiopia (Birhane et al., 2010), (31 to 64\% colonization) in acacia and prosopis tree species in Senegal (Ingleby et al., 1997), (35 to 65\% colonization) in acacia tree species, in India (Lakshman et al., 2001) and (56 to $73 \%$ colonization) in A. farnesiana and $A$. planifrons, in India (Udaiyan et al., 1996). This study showed intra- and interspecific variations in AM colonization among acacia plants (Table 3 ).

The AM colonization reported in acacia species in our study supports the view that legumes have a high mycorrhizal dependency, as pointed out by Plenchette et al. (1983). Correlation analysis showed that arbuscular colonization was positively correlated with hyphal and vesicular colonization (Lingfei et al., 2005). Concerning soil parameters, though not significant at $p<0.05$, there was an indication of positive correlation between percentages of hyphal colonization and organic carbon (0.536) and a negative correlation between hyphal colonization and available $P(-0.454)$, a result that is similar to the work of Lingfei et al. (2005). Also, Kahiluoto et al. (2001) suggested a negative correlation between available phosphorus and AM colonization.Significant variation in the abundance of AMF spores was found in the rhizosphere soil of acacia tree species in the same or different plant community (Figure 2). The mean number of spores per $100 \mathrm{~g}$ of soil ranged from 307 to 1506 with an average of 994. Other studies in similar or different host plants of the tropical area corroborate our finding: 775 to 1240 spores $100 \mathrm{~g}^{-1}$ soil in A. albida Del. in Senegal (Diop et al., 1994); 500 to 1500 spores $100 \mathrm{~g}^{-1}$ soil in $A$. farnesiana and $A$. planifrons in moderately fertile alkaline soils in India (Udaiyan et al., 1996); 110 to 2600 spores $100 \mathrm{~g}^{-1}$ soil in tropical forest and pasture (Picone, 2000) and 5 to 6400 spores $100 \mathrm{~g}^{-1}$ soil in a valley savanna of the dry tropics (Tao et al., 2004). By contrast, low spore densities of 11 to 32 spores $100 \mathrm{~g}^{-1}$ soil were detected in dry deciduous woodlands of Northern Ethiopia associated with different acacia species (Birhane et al., 2010).

Low AMF spore numbers were also recorded in a survey of acacia tree species (49 to 67 spores $100 \mathrm{~g}^{-1}$ soil) in India (Lakshman et al., 2001) and in acacia and prosopis tree species (8 to 51 spores $100 \mathrm{~g}^{-1}$ soil) in Senegal (Ingleby et al., 1997). The variation in AMF spore density between samples could be due to factors such as climatic and edaphic properties, spatial and temporal variation, vegetation, host-specificity between fungi and plants, age of the host plants, disturbance, and differential sporulation ability of AMF taxa (Husband et al., 2002; Muthukumar and Udaiyan, 2002).

The highest numbers of AMF spores were recorded in the rhizosphere soil of $A$. seyal from the open grazing 
field at Zeway, and these numbers were also higher than the same species at Zeway and at Bishoftu protected forest relics. In addition, the spore count obtained in the rhizosphere soil of $A$. seyal from OGF was highly significantly greater than the spore count in $A$. nilotica from PFR-HU, $A$. abyssinica from PP and $A$. robusta from CPFR, respectively (Figure 2). According to Janos (1992) and Picone (2000), disturbed ecosystems induce AMF to sporulate because of grazing, disturbance and slow rate of decomposition. This is however in contrast to the conclusion of Birhane et al. (2010), who suggested that management in the form of exclosure (that excludes grazing) had a positive effect on spore abundance. The percentage of root colonization and the number of AMF spores observed in the sampled acacia trees did not correlate significantly $(r=0.48, p>0.05)$. This finding is in line with results obtained by Becerra et al. (2009). The relationship between AMF spore density and percentage of root colonization are influenced by many biotic and abiotic environmental factors such as AM fungal species, plant host and soil nutrients (Stutz and Morton, 1996). The present study showed a significant negative correlation between spore density and available $P(r=-$ $0.728, p<0.01$, Figure 3 ), which is similar to some reports from India and Northern Europe (Udaiyan et al., 1996; Kahiluoto et al., 2001). The decrease in spore density with an increase in soil available $P$ observed in the study can be attributed to the fact that, available soil phosphorus suppresses AM root colonization as well as AMF density (Kahiluoto et al., 2001).

In contrast to our finding, Muleta et al. (2007) observed a positive relationship between spore number and available $P$ in soil samples from natural coffee forest inEthiopia. They suggested that the characteristics of available $P$ level in their study were not high enough to influence mycorrhizal development. As far as soil texture is concerned, spore density showed a significant positive correlation with sandy soil and negative correlation with clay soil $(r=0.604$ and $-0.710 ; p<0.05$ and 0.01 , respectively). This result is in line with the findings of Carrenho et al. (2007) who suggested that sandy soil stimulated the development of mycorrhizal association while clay soil inhibited it. This may be because sandy soils are usually more porous, warmer, drier, and less fertile than those of a finer texture and these conditions have direct and indirect effects on AMF (Sylvia and Williams, 1992). In this study, both high spore density and diversity AMF species were observed in the rhizosphere of acacia trees. Based on spore morphology, 41 AMF species and 5 morphotypes were identified (Table 4). Similarly, 44 and 60 AM fungal species were detected from semiarid grasslands of Namibia (Uhlmann et al., 2004) and sub-Saharan Savannas of Benin, West Africa (Tchabi et al., 2008), respectively. Likewise, 43 species of AMF were isolated from Western Brazilian Amazon (Stürmer and Siqueira, 2011).

The high AMF species richness observed in our acacia study is in contrast to the only 17 AMF species isolated from tropical humid high land of Kenya (Jefwa et al., 2009). Mathimaran et al. (2007) found 18 species in Kenyan ferralsol soil and Emmanuel et al. (2010) recorded 17 AMF species from soil fertility management systems in Nigeria. According to Helgason et al. (1998), woodlands have higher AM fungal species richness and diversity compared to agricultural ecosystems. Generally, Acaulospora and Funneliformis were the dominant genera accounting for 9 and 6 species, respectively. This result is similar to that observed in tropical systems in the hot-dry valley of the Jinsha River, Southwest China (Zhao and Zhao, 2007), in Panama (Mangan et al., 2004), and in Brazil (Stürmer et al., 2006). The dominance of these two genera may be related to their sporogenous characteristics, that is, the production of relatively small spores within a short period of time compared with the large spores of Gigaspora and Scutellospora genera (Hepper, 1984; Bever et al., 1996). Among the 41 species identified, the most frequently encountered were Claroideoglomus luteum, Glomus aggregatum, $C$. claroideum, C. etunicatum and Funneliformis geosporus (Table 4). Other studies have also shown that these species are repetitively detected in temperate and tropical ecosystems (Stutz et al., 2000; Oehl et al., 2003; Zhao and Zhao, 2007). On the other hand, AMF species such as G. hoi, A. capsicula, A. cavarnata, A. faveata, A. tuberculata, Diversispora celata, Entrophospora nevadensis, Rhizophagus clarus, G. decipiens, G. margarita and Racocetra fulgida occurred only in one of the acacia species suggesting that they are specific in their distribution.

We found a significant positive correlation between relative abundance and isolation frequency of AMF species $(r=0.881, p<0.01)$ indicating that species producing more spores usually had a wider distribution, while species with small geographic ranges usually produced fewer spores (Zhao and Zhao, 2007). Within the limits of the sampling areas, our study showed relatively high mycorrhizal colonization but very high AMF species diversity in the rhizosphere soil of different acacia species growing in Ethiopia. The study also indicated that AMF spore density and the extent of AMF colonization in acacia roots was influenced by soil factors such as available $\mathrm{P}$ and soil texture. The results obtained have wider implications for improving restoration success of soil fertility in degraded soils. Our small-scale field survey confirms that attention should be given to woody legumes of high mycorrhizal dependency that have high agroforestry importance in the country.

\section{ACKNOWLEDGEMENTS}

We wish to thank the School of Graduate Study, Addis Ababa University for financial assistance and Asfaw Dillo for his support and co-operation during field sample 
collection.

\section{REFERENCES}

Anon (1983). Acacia mangium and other Acacias of the humid tropics. National Academy Press, Washington, D.C.

Becerra AG, Cabello M, Zak MR, Bartoloni N (2009). Arbuscular mycorrhizae of dominant plant species in Yungas forests, Argentina. Mycologia 101:612-621.

Bever JD, Morton JB, Antonovics J, Schultz PA (1996). Host-dependent sporulation and species diversity of arbuscular mycorrhizal fungi in Mown grassland. J. Ecol. 84:71-82.

Birhane E, Kuyper TW, Sterck FJ, Bongers F (2010). Arbuscular mycorrhizal associations in Boswellia papyrifera (frankincense-tree) dominated dry deciduous woodlands of Northern Ethiopia. For. Ecol. Manage. 260:2160-2169.

Brewbaker JL (1986). Nitrogen fixing trees for foder and browse in Africa. In: Kang BT, Reynods L (eds) Alley farming in the humid and sub humid tropics: Proceeding of a working held at Ibalan Nigeria, IDRC, Ittawa, pp 58-70.

Brundrett M, Bougher N, Dell B, Grove T, Malajczuk N (1996). Working with mycorrhizas in forestry and agriculture. ACIAR Monograph 32. $374+x$ p.

Carrenho R, Trufem SFB, Bononi VLR, Silva ES (2007). The effect of different soil properties on arbuscular mycorrhizal colonization of peanuts, sorghum and maize. Acta. Bot. Bras. 21:723-730.

Craig GF, Atkins CA, Bello DT (1991). Effects of salinity on growth of four strains of Rhizobium and their infectivity on two species of acacia. Plant Soil 133:253-262.

da Silva Sousa C, Cezar Menezes RS, de Sá Barreto Sampaio EV, de Sousa Lima F, Oehl F, Costa Maia L (2013). Arbuscular mycorrhizal fungi within agroforestry and traditional land use systems in semi-arid Northeast Brazil. Acta Scient. Agron. 35:307-314.

Diop TA, Gueye M, Dreyfus BL, Plenchette C, Strullu DG (1994). Indigenous arbuscular mycorrhizal fungi associated with Acacia albida Del. in different areas of Senegal. Appl. Environ. Microbiol. 60:3433-3436.

Dommergues YR (1987). The role of biological nitrogen fixation in agroforestry. In: Steppler HA, Nair PKR (eds) Agroforestry, a decade of development. ICRAF, Nairobi, Kenya, pp 245-271.

Emmanuel B, Fagbola O, Abaidoo R, Osonubi O, Oyetunji O (2010). Abundance and distribution of arbuscular mycorrhizal fungi species in long-term soil fertility management systems in Northern Nigeria. J. Plant Nutr. 33:1264-1275.

Eshete G, Stahl G (1999). Tree rings as indicators of growth periodicity of acacias in the Rift Valley of Ethiopia. For. Ecol. Manage. 116:107117.

Garedew E, Sandewall M, Söderberg U, Campbell BM (2009). LandUse and Land-Cover Dynamics in the Central Rift Valley of Ethiopia. Environ. Manage. 44:683-694.

Gavito ME, Pérez-Castillo D, González-Monterrubio CF, VieyraHernández T, Martínez-Trujillo M (2008). High compatibility between arbuscular mycorrhizal fungal communities and seedlings of different land use types in a tropical dry ecosystem. Mycorrhiza 19:47-60.

Gerdemann JW, Nicolson TH (1963). Spores of mycorrhizal Endogone species extracted from soil by wet sieving and decanting. Tran. Br. Mycol. Soc. 46:235-244

González-Cortés JC, Vega-Fraga M, Varela-Fregoso L, MartínezTrujillo M, Carreón-Abud Y, Gavito ME (2012). Arbuscular mycorrhizal fungal (AMF) communities and land use change: the conversion of temperate forests to avocado plantations and maize fields in central Mexico. Fungal Ecol. 5:16-23.

Helgason T, Daniell TJ, Husband R, Fitter AH, Young JPW (1998). Ploughing up the wood-wide web? Nature 394:431.

Hepper CM (1984). Isolation and culture of VA Mycorhizal (VAM) fungi. In: Powell CL, Bagyaraj DJ (Eds) VA Mycorrhiza: CRC Press, Florida, USA, pp. 95-112.

Hunde A, Thulin M (1989). Mimosoideae. In: Hedberg I, Edwards S (eds) Flora of Ethiopia: The National Herbarium, Addis Ababa University, Ethiopia. pp. V(3)71-96.
Husband R, Herre EA, Young JPW (2002). Temporal variation in the arbuscular mycorrhizal communities colonising seedlings in a tropical forest. FEMS Microbiol. Ecol. 42:131-136.

Ingleby K, Diagne O, Deans JD, Lindley DK, Neyra M, Ducousso M (1997). Distribution of roots, arbuscular mycorrhizal colonisation and spores around fast-growing tree species in Senegal. For. Ecol. Manage. 90:19-27

Janos DP (1992). Heterogeneity and scale in tropical vesiculararbuscular mycorrhiza formation. In: Read DH, Lewis DH, Fitter $\mathrm{AH}$, Alexander IJ (Eds) Mycorrhizas in ecosystems: CAB International, Wallingford, England, pp 276-282.

Jefwa JM, Mung'atu J, Okoth P, Muya E, Roimen H, Njuguini S (2009). Influence of land use types on occurrence of arbuscular mycorrhizal fungi in the high altitude regions of Mt. Kenya. Trop. Subtrop. Agroecosyst. 11:277 - 290.

Kahiluoto H, Ketoja E, Vestberg M, Saarela I (2001). Promotion of AM utilization through reduced $P$ fertilization 2 . Field studies. Plant and Soil 231:65-79.

Lakshman HC, Rajanna L, Inchal RF, Mulla FI, Srinivasulu Y (2001). Survey of VA- mycorrhizae in agroforestry and its implications on forest trees. Trop. Ecol. 42(2):283-286.

Li LF, Li T, Zhao ZW (2007). Differences of arbuscular mycorrhizal fungal diversity and community between a cultivated land, an old field, and a never-cultivated field in a hot and arid ecosystem of southwest China. Mycorrhiza 17:655-665.

Lingfei L, Anna Y, Zhiwei Z (2005). Seasonality of arbuscular mycorrhizal symbiosis and dark septate endophytes in a grassland site in southwest China. FEMS Microbiol. Ecol. 54:367-373.

Mangan SA, Eom A-H, Adler GH, Yavitt JB, Herre EA (2004). Diversity of arbuscular mycorrhizal fungi across a fragmented forest in Panama: insular spore communities differ from mainland communities. Oecologia 141:687-700.

Mason PA, Wilson $\mathrm{J}$ (1994). Harnessing symbiotic associations: vesicular-arbuscular mycorrhizas. In: Leakey RRB, Newton AC (eds) Tropical trees: the potential for domestication and the rebuilding of forest resources. London, HMSO, pp 165-175.

Mathimaran N, Ruh R, Jama B, Verchot L, Frossard E, Jansa J (2007). Impact of agricultural management on arbuscular mycorrhizal fungal communities in Kenyan ferralsol. Agric. Ecosyst. Environ. 119:22-32.

McGonigle TP, Miller MH, Evans DG, Fairchild GL, Swan JA (1990). A new method which gives an objective measure of colonization of roots by vesicular-arbuscular mycorrhizal fungi. New Phytol. 115:495501.

Michelsen A (1993). Growth improvement of Ethiopian acacias by addition of vesicular-arbuscular mycorrhizal fungi or root of native plants to non sterile nursery soil. For. Ecol. Manage. 59:193-206.

Muleta D, Assefa F, Nemomissa S, Granhall U (2007). Composition of coffee shade tree species and density of indigenous arbuscular mycorrhizal fungi (AMF) spores in Bonga natural coffee forest, southwestern Ethiopia. For. Ecol. Manage. 241:145-154.

Muthukumar T, Udaiyan K (2002). Seasonality of vesicular-arbuscular mycorrhizae in sedges in a semi-arid tropical grassland. Acta. Oecologica 23:337-347.

Ndoye F, Kane A, Ngonkeu Mangaptché EL, Bakhoum N, Sanon A, Diouf D, Ourèye Sy M, Baudoin E,Noba K, Prin Y (2012). Changes in land use system and environmental factors affect arbuscular mycorrhizal fungal density and diversity, and enzyme activities in rhizospheric soils of Acacia senegal (L.) Willd. ISRN Ecology 2012: Article ID 563191, 13 pages, doi:10.5402/2012/563191.

Ngulube MR, Chapola GBJ, Mwabumba L (1993). The potential of Australian dry zone acacias for agroforestry in Malawi. For. Ecol. Manage. 56:83-97.

Oehl F, Sieverding E, Ineichen K, Mäder P, Boller T, Wiemken A (2003). Impact of land use intensity on the species diversity of arbuscular mycorrhizal fungi in agroecosystems of central Europe. Appl. Environ. Microbiol. 69:2816-2824

Omar MB, Bolland L, Heather WA (1979). A permanent mounting medium for fungi. Bull. Br. Mycol. Soc. 13:31-32.

Picone C (2000). Diversity and abundance of arbuscular-mycorrhizal fungus spores in tropical forest and pasture. Biotropica 32:734-750.

Plenchette C, Fortin JA, Furlan V (1983). Growth responses of several plant species to mycorrhizae in a soil of moderate P-fertility. I. Mycor- 
rhizal dependency under field conditions. Plant and Soil 70:199-209.

Requena N, Perez-Solis E, Azcon-Aguilar C, Jeffries P, Barea J-M (2001). Management of indigenous plant-microbe symbioses aids restoration of desertified ecosystems. Appl. Environ. Microbiol. 67:495-498.

Sanders L, Clapp JP, Wiemken A (1996). The genetic diversity Of AM fungi in natural ecosystems: key to understanding the ecology and functioning of the mycorrhizal symbiosis. New Phytol. 133:123-134.

Schenck NC, Perez Y (1990). Manual for the identification of VA mycorrhizal Fungi, $3^{\text {rd }}$ edn. Synergistic publications, Gainesville, Fla.

Schüßler A, Walker C (2010). The Glomeromycota. A species list with new families and new genera. Published in December 2010 in libraries at The Royal Botanic Garden Edinburgh, The Royal Botanic Garden Kew, Botanische Staatssammlung Munich, and Oregon State University. Electronic version freely available at www.amfphylogeny.com.

Smith SE, Read DJ (2008). Mycorrhial symbiosis $3^{\text {rd }}$ Ed. Elsevier Ltd.

Stürmer SL, Filho OK, de Queiroz MH, de Mendonça MM (2006). Occurrence of arbuscular mycorrhizal fungi in soils of early stages of a secondary succession of Atlantic forest in South Brazil. Acta Bot. Bras. 20:513-521.

Stürmer SL, Siqueira JO (2011). Species richness and spore abundance of arbuscular mycorrhizal fungi across distinct land uses in Western Brazilian Amazon. Mycorrhiza 21:255-267.

Stutz JC, Copeman R, Martin CA, Morton JB (2000). Patterns of species composition and distribution of arbuscular mycorrhizal fungi in arid regions of southwestern North America and Namibia, Africa. Can. J. Bot. 78: 237-245.

Stutz JC, Morton JB (1996). Successive pot cultures reveal high species richness of arbuscular endomycorrhizal fungi in arid ecosystems. Can. J. Bot. 74:1883-1889.

Sylvia DM, Williams SE (1992). Vesicular-arbuscular mycorrhizae and environmental stress. In: Bethlenfalvay GJ, Linderman RG (eds) Mycorrhizae and sustainable agriculture. Madison, ASA Special Publication, pp 101-124.

Tao L, Jianping L, Zhiwei Z (2004). Arbuscular mycorrhizas in a valleytype savanna in southwest China. Mycorrhiza 14:323-327.

Tchabi A, Coyne D, Hountondji F, Lawouin L, Wiemken A, Oehl F (2008). Arbuscular mycorrhizal fungal communities in sub-Saharan Savannas of Benin, West Africa, as affected by agricultural land use intensity and ecological zone. Mycorrhiza 18:181-195.
Udaiyan K, Karthikeyan A, Muthukumar T (1996). Influence of edaphic and climatic factors on dynamics of root colonization and spore density of vesicular-arbuscular mycorrhizal fungi in Acacia farnesiana Willd. and A. planifrons W.et.A. Trees 11: 65-71.

van der Heijden, MAG, Klironomos JN, Ursic M, Moutoglis P, StreitwolfEngel R, Boller T, Wiemken A, Sanders IR (1998). Mycorrhizal fungal diversity determines plant biodiversity, ecosystem variability and productivity. Nature 396: 69-72.

Uhlmann E, Görke C, Petersen A, Oberwinkler F (2004). Arbuscular mycorrhizae from semiarid regions of Namibia. Can. J. Bot. 82:645653.

Walker C, Mize CW, McNabb HS (1982). Populations of endogonaceous fungi at two locations in lowa. Can. J. Bot. 60:25182529.

Wubet T, Weiß M, Kottke I, Teketay D, Oberwinkler F (2003). Molecular diversity of arbuscular mycorrhizal fungi in Prunus africana, an endangered medicinal tree species in dry Afromontane forests of Ethiopia. New Phytol. 161:517-528.

Yohannes Y, Assefa F (2007). Phenotypic characteristics of root nodule bacteria and arbuscular mycorrhizal fungi infecting Acacia polyacantha growing in Ghibe wooded grasslands. Ethio. J. Natu. Sci. 9(1):123-139.

Zhao DD, Zhao ZW (2007). Biodiversity of arbuscular mycorrhizal fungi in the hot-dry valley of the Jinsha River, Southwest China. Appl. Soil Ecol. 37:118-128. 